\title{
Productivity and physiological quality of seeds with burn down herbicides at the pre harvest of bean crops ${ }^{1}$
}

\author{
Marlo Adriano Bison Pinto ${ }^{2 *}$, Claudir José Basso², \\ Stela Maris Kulczynski², Cristiano Bellé
}

\begin{abstract}
The physiological quality of bean seeds is influenced by the production environment and management practices employed during cultivation. The objective of this study was to evaluate the productivity and physiological quality of bean seeds after desiccant applications at different times at pre-harvest. A randomized block design was used, with a factorial $(3 \times 3)+1$ arrangement, where the application of three desiccants was tested: glyphosate $\left(960 \mathrm{~g}\right.$ a.i. ha $\left.{ }^{-1}\right)$, paraquat dichloride (240 g a.i. ha $\left.{ }^{-1}\right)$ and glufosinate ammonium (400 g a.i. ha $\left.{ }^{-1}\right)+$ mineral oil, applied three times (days after flowering - DAF), and a control without herbicide in four replications. Seed quality was determined by the following tests: germination, first count, seedling emergence speed rate, accelerated aging, electrical conductivity and seedling dry biomass. Seed yield was not influenced by either herbicides or time of application. Regardless of time of application, the lowest percentage of normal seedlings after the germination, first count and accelerated aging tests was observed in seeds desiccated with the herbicide glufosinate ammonium. The herbicide glyphosate reduces seedling vigor. The times of application of the product paraquat dichloride did not affect the germination and vigor of bean seeds.
\end{abstract}

Index terms: Phaseolus vulgaris L., herbicide, germination.

\section{Produtividade e qualidade fisiológica das sementes com dessecação na pré- colheita do feijoeiro}

RESUMO - A qualidade fisiológica de sementes de feijão é influenciada pelo ambiente de produção e por práticas de manejo empregadas durante o cultivo. O objetivo do trabalho foi avaliar a produtividade e qualidade fisiológica de sementes de feijão, após aplicações de herbicidas dessecantes em diferentes épocas na pré-colheita. Utilizou-se o delineamento de blocos ao acaso, em esquema fatorial $(3 \times 3)+1$, onde se testou a aplicação de três herbicidas dessecantes: glyphosate $\left(960 \mathrm{~g} \mathrm{de} \mathrm{ia.ha}^{-1}\right)$, dicloreto de paraquat (240 $\mathrm{g}$ de ia.ha-1 ${ }^{-1}$ e glufosinato de amônio (400 g de ia.ha $\left.{ }^{-1}\right)+$ óleo mineral, aplicados em três épocas (dias após o florescimento - DAF), mais uma testemunha sem aplicação de herbicida, em quatro repetições. A qualidade fisiológica das sementes foi determinada por meio dos testes de germinação, primeira contagem, índice de velocidade de emergência de plântulas, envelhecimento acelerado, condutividade elétrica e biomassa seca de plântulas. A produtividade de sementes não é influenciada pelos herbicidas e épocas de aplicação. Independente da época de aplicação, a menor percentagem de plântulas normais no teste de germinação, envelhecimento acelerado e primeira contagem, é de sementes dessecadas com o herbicida glufosinato de amônio. O herbicida glyphosate reduz o vigor de plântulas. As épocas de aplicação para o produto dicloreto de paraquat não afetam a germinação e o vigor das sementes de feijão.

Termos de indexação: Phaseolus vulgaris L., herbicida, germinação.

\section{Introduction}

Advances in genetic breeding and irrigation systems, and the use of mechanical harvesting have increased yield and quality of bean crops. However, physiological characteristics of bean plants, added to unfavorable environmental conditions,

${ }^{1}$ Submitted on $05 / 26 / 2014$. Accepted for publication on 09/11/2014. ${ }^{2}$ Departamento de Ciências Agronômicas e Ambientais, UFSM, Caixa Postal 54, 98400-000 - Frederico Westphalen, RS, Brasil. make the time of harvest a very delicate operation, because the physiological maturity of seeds occurs with high water content; basal internodes of the plants are short; and height of pod insertion is low. Additionally, delayed harvesting exposes the seeds to deterioration by microorganisms, fluctuations in temperature and relative humidity, rainfall and natural pod

${ }^{3}$ Departamento de Fitossanidade, UFPel, Caixa Postal 354, 96010-900 Pelotas, RS, Brasil.

*Corresponding author <marlo.bison@gmail.com> 
shattering, causing loss of yield and physiological quality at pre-harvest (Lacerda et al., 2005; Kamikoga et al., 2009; Kappes et al., 2009; Botelho et al., 2010).

The use of desiccants has been observed in various crops in order to maintain productivity and mitigate problems such as the reduction of germination percentage and seed vigor (Caierão and Acosta, 2007; Kappes et al., 2008; Kappes et al., 2009; Daltro et al., 2010; Foloni et al., 2011). In bean plants, the use of these products is relatively recent; however, interest in this practice is increasing in producing regions, and related advantages include the possibility of harvest planning, increased efficiency of machines, faster release of the area for subsequent crops and reduction of damage caused by pests and fungi that may attack crops at the end of the cycle.

Among the products available in the market, the herbicides paraquat dichloride, glufosinate ammonium and glyphosate have proven efficient as desiccants in some crops, and they are registered by the Ministry of Agriculture, except for glyphosate. Paraquat dichloride and glufosinate ammonium are contact herbicides that act quickly upon plants, causing toxicity a few hours after application. However, translocation of glufosinato ammonium in plants, although limited, is higher than that of paraquat dichloride; therefore, there is more damage to the plant tissues when the former is applied early (Lacerda et al., 2005). In contrast, glyphosate is a post-emergent, non-selective, systemic herbicide for broad-spectrum control. It belongs to the chemical group of N-substituted glycines (Vargas et al., 2007). Although it is not registered, as above mentioned, it has been widely used in various regions of Brazil, mainly because of its good cost-benefit ratio compared with other herbicides (França-Neto et al., 2007).

Given the increasing number of crops in agricultural areas, aimed at greater optimization, the cycles of each crop are becoming shorter, and the beans end up with uneven physiological maturity. The use of desiccants to accelerate the release of the area for the next crop has increased continuously. Knowledge of the effect of desiccants on seed quality, therefore, is extremely important to avoid any loss of quality during cultivation. Thus, the aim of this study was to evaluate yield and physiological quality of seeds in different positions in the plant after the use of pre-harvest desiccants on bean plants in the off-season in northwestern Rio Grande do Sul.

\section{Material and Methods}

The study was carried out in two stages: the field stage was conducted at $27^{\circ} 36^{\prime} 25^{\prime} \mathrm{S}$ (latitude), 53'21'19'W (longitude); average altitude is $558 \mathrm{~m}$, and the soil is a typical eutrophic red oxisol (Embrapa, 2006). Cultivar IPR Gralha, commercial black beans (type I) was used. Mechanical sowing was performed with 19 seeds per meter of furrow at a depth of $0.05 \mathrm{~m}$ and $0.45 \mathrm{~m}$ spacing between rows. The plots were comprised of 10 rows of $4.5 \mathrm{~m}$ length, separated by 0.50 $\mathrm{m}$ in the row and $1 \mathrm{~m}$ between rows. Seedling emergence occurred six days after seeding, with an estimated population of 360,000 plants.ha ${ }^{-1}$. During the experiment, there was no water restriction to the normal development of the crop.

By the time of desiccant applications, the first application time (39 DAF) was considered to be the one where $50 \%$ of the pods had physiological maturity as indicated by their color (Vieira et al., 2006). The other application times were determined as days after the first application; they were performed on the fifth (44 DAF) and tenth (49 DAF) days. The applications were performed in the morning, with a $\mathrm{CO}_{2}$ pressurized backpack sprayer calibrated to a volume of 200 L.ha $^{-1}$. The plots were harvested when the plants were visually dry. Grain yield, hundred seed weight (HSW) and seed quality were evaluated. For the evaluations of these variables, the eight central rows of each plot were considered as useful area, while $0.5 \mathrm{~m}$ was disregarded in the extremities $\left(12.6 \mathrm{~m}^{2}\right)$.

The harvest was manual and the track was made using a stationary harvester. The yield for each plot was measured by weighing the seeds on a precision balance, and the values were converted into kg.ha-1 ${ }^{-1}$ Hundred seed weight (HSW) was measured with the methodology proposed by Brasil (2009). Moisture was adjusted to $13 \%$ for both variables.

The second stage of the experiment, relative to assessments of physiological seed quality, was held with ten plants randomly collected within the useful plot. Seeds were collected at two locations in the plant: in the lower portion (base) and the upperportion (apex). The seeds of each portion were analyzed individually. After the study sample was set up, it was taken to the laboratory, and the physiological quality of seeds was determined by the following tests:

Germination (GT)- eight replicates of 50 seeds per treatment were arranged in rolls of paper, moistened with distilled water corresponding to 2.5 times the weight of the dry paper. The rolls were stored in sealed plastic bags and kept in a B.O.D. incubator at $25^{\circ} \mathrm{C}$ for 9 days. The evaluation was conducted at five and nine days after sowing; the percentage of normal seedlings was measured;

First count (FC) - performed together with the germination test; the number of normal seedlings was assessed on the 5th day after the start of the test. The results were expressed as percentage of normal seedlings;

Seedling emergence speed rate (ESR) - evaluated in a greenhouse by sowing four replicates of 25 seeds per treatment, in plastic trays containing substrate for ornamental plants. The trays were irrigated and counts were performed daily after the 
emergence of the first seedling. Calculation of ESR (eq. 1) was based on the methodology proposed by Maguire (1962).

Accelerated aging (AA) - four replicates of 50 seeds of each treatment were laid out in a single layer on a screen inside gerboxes, avoiding contact with $40 \mathrm{~mL}$ of distilled water placed at the bottom. The gerboxes were sealed and kept inside an oven at $42{ }^{\circ} \mathrm{C}$ for 72 hours. Immediately after the end of the aging period, each replicate was placed in paper towel rolls, and exposed to the same conditions described for the germination test, but the percentage of normal seedlings was assessed at five days after sowing.

Electrical conductivity (EC) - conducted through the center-of-mass system with four replicates of 50 seeds per treatment. The seeds were accurately weighed to two decimal places after the decimal point, and then placed in $200 \mathrm{~mL}$ plastic cups filled with $75 \mathrm{~mL}$ distilled water, and kept in an incubator at a constant temperature of $25^{\circ} \mathrm{C}$. After 24 hours of soaking, electrical conductivity was measured in the soaking solution, using a digital conductivity meter whose results were expressed in $\mu \mathrm{S} . \mathrm{cm}^{-1} . \mathrm{g}^{-1}$;

Seedling dry biomass ( $D B$ ) -measured in parallel to the germination test by randomly selecting four replicates of 10 normal seedlings per treatment. They were fully packed in paper bags and taken to dry in a forced air circulation oven at $60 \pm 2{ }^{\circ} \mathrm{C}$ for 48 hours. The material was then weighed for the dry biomass of 10 seedlings, with an accuracy of $0.001 \mathrm{~g}$.

The experiment used a randomized block design, with a factorial $(3 \times 3)+1$ scheme, comprised of three desiccants glyphosate $\left(960 \mathrm{~g}\right.$ a.i. ha $\left.{ }^{-1}\right)$, paraquat dichloride $\left(240 \mathrm{~g}\right.$ a.i. ha $\left.{ }^{-1}\right)$ and glufosinate ammonium (400 g a.i. ha $\left.{ }^{-1}\right)+$ mineral oil, applied at three times (days after flowering - DAF), and a control without herbicide application, in four replications.

The results were subjected to analysis of variance by the F-test; thus, the significance of the treatments (desiccants and application times) and of the evaluation were checked for position in the plant. For statistical differences, Tukey's test $(p<0.05)$ was used for the treatment (desiccants) and the evaluation (position in the plant). In the evaluation of application times, the polynomial regression method was used for obtaining statistical differences. The control was compared individually with each treatment by Dunnett's test $(\mathrm{p}<0.05)$. Statistical analysis was performed with the aid of the statistical software Statistical Analysis System SAS 8.0 (SAS Institute, 2003).

\section{Results and Discussion}

The results in Table 1 show that the desiccant had no influence on yield and hundred seed weight of the crop, whereas hundred seed weight was influenced by time of application. The seeds of plants desiccated at 39 DAF had the lowest weight (Figure 1). These results are similar to those described by Kamikoga et al. (2009) and Coelho et al. (2012), who observed a linear and growing relationship in seed weight when the number of applications increased from 28 to 43 DAF. No direct influence of hundred seed weight was observed on yield. This is contrary to the results obtained by Penckowski, 2005; Kappes et al. (2012), who reported the occurrence of a positive linear effect on yield as desiccation was delayed. It should be noted that yield is dependent on genotype, crop and environment, as well as the interaction between these factors, achieved through assessments of adaptability and stability (Rocha et al., 2010).

Table 1. Average values of hundred seed weight (HSW) and yield (Y) of off-season beans, Gralha cultivar, desiccated with different herbicides and days after flowering (DAF).

\begin{tabular}{ccc}
\hline Treatments & HSW $(\mathrm{g})$ & $\mathrm{Y}\left(\mathrm{kg} \cdot \mathrm{ha}^{-1}\right)$ \\
\hline Herbicides $-H$ & & \\
Glyphosate & 24.45 & 2265.84 \\
P. dichloride & 23.88 & 2186.60 \\
G. ammonium & 23.89 & 2312.10 \\
Control & 24.44 & 2039.01 \\
F value ${ }^{(1)}$ & $1.67^{\mathrm{ns}}$ & $0.25^{\mathrm{ns}}$ \\
\hline Application times $-M$ & & \\
39 DAF & 23.57 & 2228.00 \\
44 DAF & 24.07 & 2307.69 \\
49 DAF & 24.59 & 2228.84 \\
F value & $4.06^{*}$ & $0.13^{\mathrm{ns}}$ \\
\hline Hx interaction & & \\
F value & $1.87^{\mathrm{ns}}$ & $0.44^{\mathrm{ns}}$ \\
Mean & 24.13 & 2224.01 \\
CV (\%) & 3.66 & 19.34 \\
\hline
\end{tabular}

${ }^{1} \mathrm{~F}$-Test. *significant $(\mathrm{p}<0.05)$. ${ }^{\text {ns }}$ non-significant $(\mathrm{p}<0.05)$. DAF: Days after flowering. P. dichloride: Paraquat dichloride. - G. ammonium: Glufosinate ammonium.

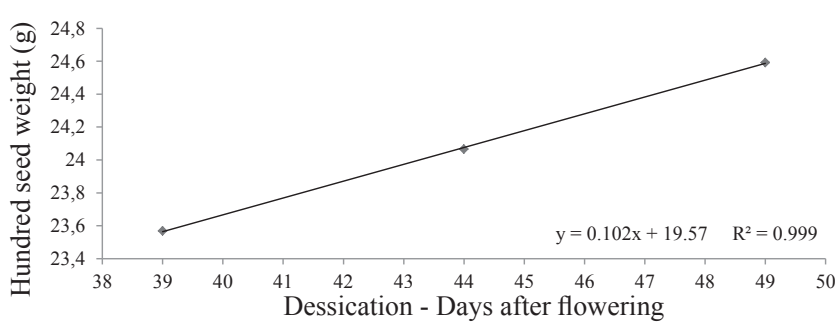

Figure 1. Effect of selective herbicides, applied at different times at pre-harvest, on hundred seed weight of off-season beans, cv. Gralha. (adjusted model is significant at $\mathrm{p}<0.05$ by the F-test). 
The results in Table 2 show that herbicides and application times affected the physiological potential of seeds, confirming what was observed by other authors (Lacerda et al., 2005;
Caierão and Acosta, 2007; Kappes et al., 2009; Daltro et al., 2010; Foloni et al., 2011; Kappes et al., 2012), whereas the position in the plant showed differences only for seed vigor.

Table 2. First count (FC), germination (GER), accelerated aging (AA), seedling dry biomass (DB), electrical conductivity (EC) and emergence speed rate (ESR) of seeds in off-season beans cv. Gralha, from two positions in the plant, desiccated with different herbicides at days after flowering (DAF).

\begin{tabular}{|c|c|c|c|c|c|c|}
\hline Treatments & $\mathrm{FC}(\%)$ & GER. $(\%)$ & AA (\%) & DB $(g)$ & $\mathrm{EC}\left(\mu \mathrm{S} . \mathrm{cm}^{-1} \cdot \mathrm{g}^{-1}\right)$ & ESR \\
\hline \multicolumn{7}{|l|}{ Herbicides - H } \\
\hline Glyphosate & 95.95 & 97.66 & 96.00 & 3.40 & 73.58 & 2.87 \\
\hline P. dichloride & 98.00 & 99.13 & 96.83 & 3.28 & 65.42 & 3.04 \\
\hline G. ammonium & 85.33 & 86.63 & 82.58 & 3.31 & 71.37 & 2.84 \\
\hline Control & 98.13 & 98.50 & 89.75 & 3.39 & 75.66 & 2.95 \\
\hline F value $^{(1)}$ & $151.90 *$ & $55.35^{*}$ & $136.56^{*}$ & $7.70^{*}$ & $17.30^{*}$ & $21.99 *$ \\
\hline \multicolumn{7}{|l|}{ Times - M } \\
\hline $39 \mathrm{DAF}$ & 87.42 & 90.08 & 86.58 & 3.34 & 76.59 & 2.81 \\
\hline $44 \mathrm{DAF}$ & 95.58 & 96.54 & 93.08 & 3.32 & 66.57 & 2.91 \\
\hline $49 \mathrm{DAF}$ & 96.79 & 97.26 & 95.75 & 3.32 & 67.21 & 2.98 \\
\hline F value & $47.03 *$ & $31.18^{*}$ & $47.47 *$ & $0.13^{\mathrm{ns}}$ & $30.57 *$ & $15.46^{*}$ \\
\hline \multicolumn{7}{|l|}{ Positions - P } \\
\hline Apex & 92.69 & 94.17 & 90.17 & 3.30 & 66.27 & 2.91 \\
\hline Base & 94.17 & 94.77 & 93.44 & 3.35 & 73.98 & 2.93 \\
\hline F value & $0.91^{\mathrm{ns}}$ & $1.82^{\mathrm{ns}}$ & $17.20^{*}$ & $5.59^{*}$ & $43.35^{*}$ & $0.89^{\text {ns }}$ \\
\hline Interaction & \multicolumn{6}{|c|}{ F value } \\
\hline H x M & $60.15^{*}$ & $27.29 *$ & $49.8^{*}$ & $7.10^{*}$ & $19.49^{*}$ & $11.12 *$ \\
\hline $\mathrm{H} \times \mathrm{P}$ & $3.67 *$ & $0.44^{\mathrm{ns}}$ & $24.65^{*}$ & $0.53^{\mathrm{ns}}$ & $2.07^{\mathrm{ns}}$ & $1.61^{\mathrm{ns}}$ \\
\hline $\mathrm{P} \times \mathrm{M}$ & $2.15^{\mathrm{ns}}$ & $1.12^{\mathrm{ns}}$ & $1.98^{\mathrm{ns}}$ & $1.41^{\mathrm{ns}}$ & $8.91 *$ & $0.27^{\mathrm{ns}}$ \\
\hline $\mathrm{H} \times \mathrm{M} \times \mathrm{P}$ & $0.98^{\mathrm{ns}}$ & $1.93^{\mathrm{ns}}$ & $0.92^{\mathrm{ns}}$ & $0.98^{\mathrm{ns}}$ & $3.33^{\mathrm{ns}}$ & $3.64^{\mathrm{ns}}$ \\
\hline CV (\%) & 4.07 & 7.01 & 3.65 & 3.20 & 7.09 & 3.92 \\
\hline
\end{tabular}

${ }^{1} \mathrm{~F}$-test. *significant $(\mathrm{p}<0.05){ }^{\text {ns }}$ non-significant $(\mathrm{p}<0.05)$. DAF: Days after flowering. P. dichloride: Paraquat dichloride. - G. ammonium: Glufosinate ammonium.

For the interaction between herbicides and application times (Table 3), regardless of time of application, the lowest percentage of normal seedlings after the germination, accelerated aging and first count tests was observed in seed plants desiccated with the herbicide glufosinate ammonium. A comparison between application times in each herbicide showed that glufosinate ammonium, during the first germination count, was the only product that had a reduction in the number of normal seedlings compared with the control treatment, at all application times.

In the germination and accelerated aging tests, the herbicide glufosinate ammonium was the only one that showed a significant difference compared with the control when applied at 39 DAF, while the percentage of normal seedlings was 28.5 and $26.2 \%$ lower, respectively. Working with herbicides and application stages in soybean, Guimarães et al. (2012) also observed that glufosinate ammonium, when applied at stage R6, resulted in a greater number of abnormal plants compared with the control treatment, including a higher percentage of abnormal seedlings than paraquat dichloride, applied at the same time. The product glufosinate ammonium translocates more easily than paraquat dichloride (Lacerda et al., 2005); there may have been local absorption of the product, sprinkled directly over the pods, and further degradation of molecules and formation of secondary metabolites. This may have caused major damage to tissues when applied at $39 \mathrm{DAF}$, contrary to the results obtained by Penckowski (2005) and Kamikoga et al.(2009), who found that glufosinate ammonium did not affect the physiological quality of bean seeds, regardless of application time.

No differences were observed in germination percentage after the accelerated aging test. The lack of difference is indicative that plant desiccation does not favor the degradation process, as noted by other authors, who evaluated seeds from desiccated plants subjected to 8-month storage, for which they found lower values for germination and vigor compared with seeds that had not been desiccated (Penckowski, 2005). 
Table 3. Values obtained in the first germination count, germination, accelerated aging and seedling dry biomass in off-season beans, depending on herbicides and application times.

\begin{tabular}{|c|c|c|c|c|c|}
\hline \multirow{2}{*}{ Herbicide } & \multicolumn{3}{|c|}{ Application times } & \multirow{2}{*}{ Equations } & \multirow{2}{*}{$\mathrm{R}^{2}$} \\
\hline & 39 & 44 & 49 & & \\
\hline \multicolumn{6}{|c|}{- First count $(\%)$} \\
\hline Glyphosate & $98.75 \mathrm{a}$ & $97.37 \mathrm{a}$ & $96.87 \mathrm{ab}$ & $y=0.017 x^{2}-1.727 x+139.50$ & 0.86 \\
\hline P. dichloride & $99.12 \mathrm{a}$ & $99.50 \mathrm{a}$ & $98.75 \mathrm{a}$ & non-significant & - \\
\hline G. ammonium & $72.37 b^{*}$ & $92.75 b^{*}$ & $94.75 b^{*}$ & non-significant & - \\
\hline \multirow{2}{*}{\multicolumn{6}{|c|}{$\begin{array}{c}98.00 \\
\text { Germination }(\%)\end{array}$}} \\
\hline & & & & & \\
\hline Glyphosate & $97.87 \mathrm{a}$ & $94.00 \mathrm{~b}$ & $99.00 \mathrm{a}$ & $y=0.177 x^{2}-15.507 x+432.69$ & 0.79 \\
\hline P. dichloride & $96.12 \mathrm{a}$ & $99.75 \mathrm{a}$ & $98.12 \mathrm{a}$ & non-significant & - \\
\hline G. ammonium & $68.25 b^{*}$ & $93.00 \mathrm{~b}$ & $94.75 \mathrm{a}$ & $y=-0.460 x^{2}+43.130 x-914.16$ & 0.76 \\
\hline \multirow{2}{*}{\multicolumn{6}{|c|}{$\begin{array}{c}95.50 \\
- \text { Accelerated aging }(\%)-\end{array}$}} \\
\hline & & & & & \\
\hline Glyphosate & $95.50 \mathrm{a}$ & $94.75 \mathrm{a}$ & $97.75 \mathrm{a}^{*}$ & $y=0.075 x^{2}-6.375 x+230.05$ & 0.99 \\
\hline P. dichloride & $98.00 \mathrm{a}^{*}$ & $95.00 \mathrm{a}$ & $97.50 \mathrm{a}^{*}$ & non-significant & - \\
\hline G. ammonium & $66.25 b^{*}$ & $89.50 \mathrm{~b}$ & $92.00 \mathrm{~b}$ & non-significant & - \\
\hline \multirow{2}{*}{\multicolumn{6}{|c|}{$\begin{array}{c}89.75 \\
\text { Seedling dry biomass }(\mathrm{g})\end{array}$}} \\
\hline & & & & & \\
\hline Glyphosate & $3.48 \mathrm{a}$ & $3.26 \mathrm{a}^{*}$ & $3.45 \mathrm{a}$ & non-significant & - \\
\hline P. dichloride & $3.23 b^{*}$ & $3.35 \mathrm{a}$ & $3.26 \mathrm{~b}$ & $y=-0.004 x^{2}+0.381 x-5.09$ & 1 \\
\hline G. ammonium & $3.30 \mathrm{ab}$ & $3.35 \mathrm{a}$ & $3.27 \mathrm{~b}$ & $y=-0.003 x^{2}+0.254-2.18$ & 0.90 \\
\hline \multirow{2}{*}{\multicolumn{6}{|c|}{$\frac{3.39}{-\mathrm{EC}\left(\mu \mathrm{S} . \mathrm{cm}^{-1} \cdot \mathrm{g}^{-1}\right)}$}} \\
\hline & & & & & \\
\hline Glyphosate & $79.22 \mathrm{a}$ & $71.68 \mathrm{a}$ & $69.82 \mathrm{a}$ & $y=0.286 x^{2}-24.57 x+588.22$ & 0.72 \\
\hline P. dichloride & $64.84 b^{*}$ & $60.65 b^{*}$ & $70.77 \mathrm{a}$ & non-significant & - \\
\hline G. ammonium & $85.70 \mathrm{a}^{*}$ & $67.38 \mathrm{ab}$ & $61.03 b^{*}$ & non-significant & - \\
\hline \multicolumn{6}{|c|}{75.66} \\
\hline \multicolumn{6}{|c|}{ Emergence Speed Rate } \\
\hline Glyphosate & $2.68 b^{*}$ & $2.92 b$ & $3.01 \mathrm{a}$ & $y=-0.005 x^{2}+0.516 x-7.95$ & 0.70 \\
\hline P. dichloride & $3.05 \mathrm{a}$ & $3.14 \mathrm{a}^{*}$ & $2.93 \mathrm{a}$ & non-significant & - \\
\hline G. ammonium & $2.70 \mathrm{~b}^{*}$ & $2.81 \mathrm{~b}$ & $2.99 \mathrm{a}$ & non-significant & - \\
\hline Control & & 2.95 & & & \\
\hline
\end{tabular}

Means followed by the same letters in the column do not differ by Tukey's test $(\mathrm{p}<0.05)$. Statistically different from the control treatment by Dunnett's test ( $\mathrm{p}$ $<0.05)$. P. dichloride: Paraquat dichloride. - G. ammonium: Glufosinate ammonium.

The test for seedling dry biomass showed that the seeds of plants that received contact herbicides in applications made at 39 and 49 DAF had lower weight compared with plants whose seeds were desiccated with glyphosate, which showed no difference across application times. A similar response was found by Kappes at al. (2012) with the use of paraquat dichloride, where there were reductions in mass accumulation for applications of $285 \mathrm{~g} \cdot \mathrm{ha}^{-1}$ and $305 \mathrm{~g} \cdot \mathrm{ha}^{-1}$, respectively made at 35 and 40 DAF.

For application times, there was an increase in the percentage of normal seedlings in the germination test of seeds that had received glufosinate ammonium; such percentage increased with the delay of applications, an identical effect to that of glyphosate from the second application time onwards (Figure 2a). However, glyphosate showed lower germination percentage when the application was made at 44 DAF, which is contrary to the finding by Kamikoga et al. (2009), who found no difference between the applications made between 28 and 43 DAF. Otherwise, the seeds that received glyphosate, showed increase in vigor with the delay of product applications, as shown in the tests for accelerated aging (Figure 2b), electrical conductivity (Figure 2c) and emergence speed rate (Figure 2d).

Application times of paraquat dichloride did not affect seed germination percentage. Response to this herbicide was observed only in the vigor expressed by the seedling dry biomass test, where the greatest weight was obtained in seeds of plants desiccated at 44 DAF. Working with rates 
and application times in early Carioca bean cultivar, Kappes et al. (2012) found similar results. Seedlings had higher dry matter accumulation when desiccated at 40 DAF, although no difference was observed when compared with the application at 45 DAF. These results corroborate those found by Guimarães et al. (2012), who studied soybean, and found that the herbicide paraquat dichloride promoted positive rates of germination and seed vigor when used at development stages R6 and R7.2 of the crop. Santos et al. (2004) claimed that knowledge of the mode of action of the herbicide is as important for maximum yield of viable seeds as knowledge of the best time for product application in bean plants. Application time and mechanism of action of the herbicide directly affect seed quality, although yield may not always be affected (Kappes et al., 2009).
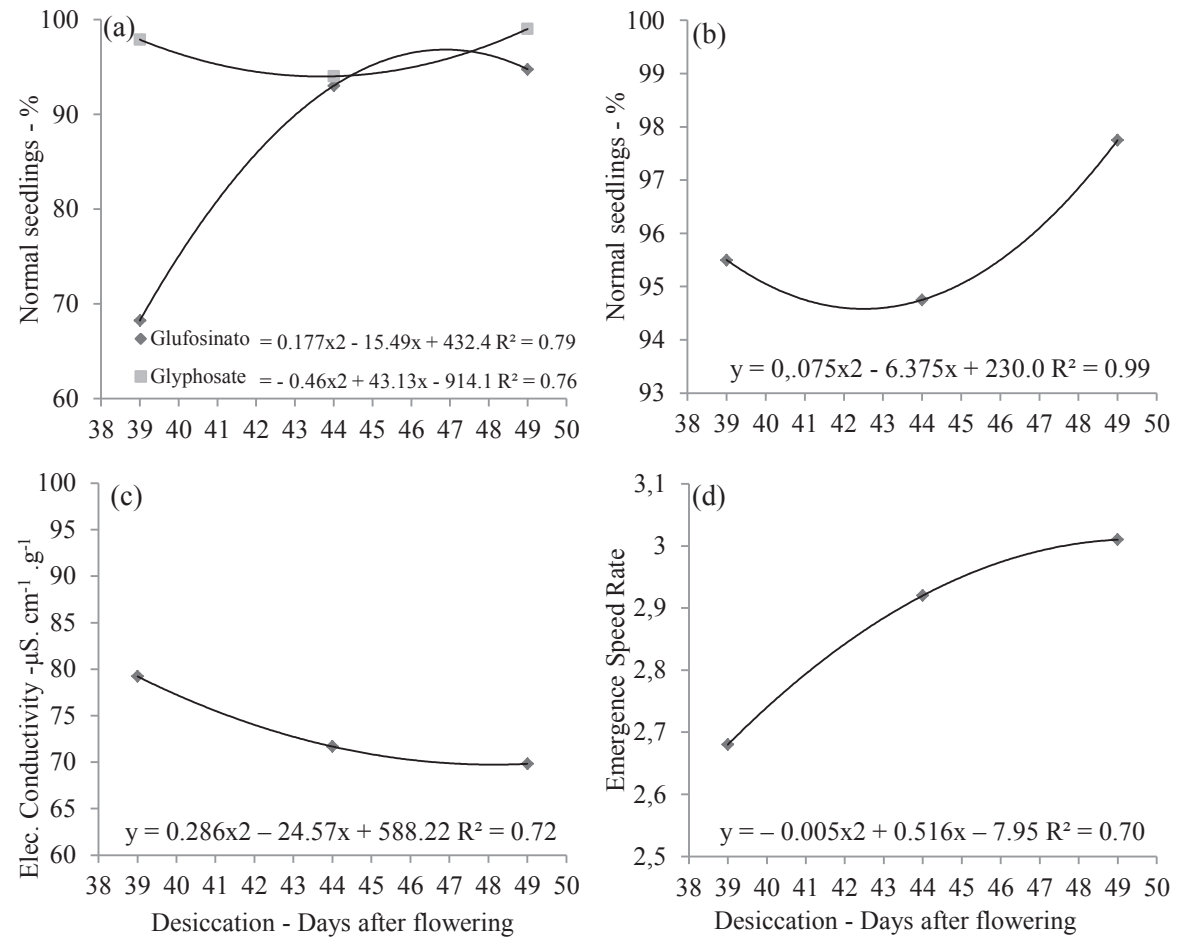

Figure 2. Regression analysis of the effect of glyphosate applied at different times after flowering in the germination (Figure 2a), accelerated aging (Figure 2b), electrical conductivity (Figure 2c) and emergence speed rate (Figure 2d) tests, for off-season bean seeds desiccated at pre-harvest. (the adjusted model is significant at $\mathrm{p}<0.05$ by the F-test).

For the interaction between herbicide and plant positions (Table 4), there was interference with the vigor expressed in the first count and accelerated aging tests. Regardless of position, seeds desiccated with glufosinate ammonium showed less vigor when compared with seeds obtained from plants desiccated with other products or with the control. Seeds from the upperportion showed less vigor when subjected to stress conditions for temperature and humidity, with reduction in the number of normal seedlings by 19.19 and $12.30 \%$ compared to the control comprised of seeds of the whole plant and seed from the lower portion, respectively. There are no clear distinction across developmental stages of bean plants, especially when plants with indeterminate habit are considered, although there is an overlap represented by the simultaneous emission of leaves, flowers and pods (Moura et al., 2012). This feature, coupled with greater ease of translocation of glufosinate ammonium (Lacerda et al., 2005), may have potentiated its action when it was sprayed directly on the pods, causing further damage to the tissues of the upper portion.

Interference effect was found in the electrical conductivity test (Table 5) for the interaction between application times and positions of the plant. No difference was observed between positions where the application of the product occurred at 39 DAF, while seeds in the upper position had higher vigor for applications carried out at 44 and 49 DAF. This result assumes that desiccation has acted upon the permeability of the seedcoat (Kikuti et al., 2006). When there is low release of solutes after sowing, there is lesser loss of cell compartmentalization, thus reducing the growth of microorganisms that are harmful to seedlings (Marcos-Filho, 2005). In addition, it was observed that the electrical conductivity test is effective in detecting differences between treatments, which agrees with the results obtained by Kikuti et al. (2006), Coelho et al. (2010) and Coelho et al. (2012). 
Table 4. First germination count and accelerated aging of off-season bean seeds, depending on positions in the plant and different herbicides.

\begin{tabular}{|c|c|c|c|c|}
\hline \multirow{2}{*}{ Position } & \multicolumn{4}{|c|}{ Herbicide } \\
\hline & Glyphosate & P. dichloride & G. ammonium & Control \\
\hline & & 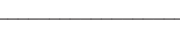 & 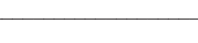 & - \\
\hline Upper & $98.83 \mathrm{aA} *$ & $98.42 \mathrm{aA}$ & $85.25 \mathrm{aB} * *$ & 98.75 \\
\hline Lower & $99.41 \mathrm{aA}$ & $96.92 \mathrm{aA}$ & $88.00 \mathrm{aB} * *$ & 98.25 \\
\hline Upper & $95.33 \mathrm{aA}$ & $98.00 \mathrm{aA}$ & $77.17 \mathrm{bB} * *$ & 93.50 \\
\hline Lower & $96.67 \mathrm{aA}$ & $95.67 \mathrm{aA}$ & $88.00 \mathrm{aB} * *$ & 96.00 \\
\hline
\end{tabular}

Means followed by the same letters do not differ by Tukey's test $(\mathrm{p}<0.05)$. Uppercase letters are compared in the row and lowercase letters are compared in the column. **Statistically different from the control treatment by Dunnett's test $(\mathrm{p}<0.05)$. P. dichloride: Paraquat dichloride. - G. ammonium: Glufosinate ammonium.

Table 5. Electrical conductivity of off-season bean seeds, cv. IPR Gralha, depending on the position in the plant and application times of desiccant herbicides.

\begin{tabular}{ccccccc}
\hline \multirow{2}{*}{ Position } & \multicolumn{3}{c}{ Electrical Conductivity $\left(\mu \mathrm{S} . \mathrm{cm}^{-1} \cdot \mathrm{g}^{-1}\right)-$} & \multicolumn{2}{c}{ Equations } & \multirow{2}{*}{$\mathrm{R}^{2}$} \\
\cline { 2 - 4 } & $39^{1}$ & 44 & 49 & & non-significant & - \\
Upper & $76.07 \mathrm{a}$ & $60.15 \mathrm{~b}$ & $62.59 \mathrm{~b}$ & & $\mathrm{y}=0.367 \mathrm{x}^{2}-33.666 \mathrm{x}+830.48$ & 0.82 \\
Lower & $77.10 \mathrm{a}$ & $73.00 \mathrm{a}$ & $71.83 \mathrm{a}$ & & $\mathrm{y}$
\end{tabular}

Means followed by the same letter in the column do not differ by Tukey's test $(\mathrm{p}<0.05)$. ${ }^{1}$ Days after flowering.

\section{Conclusions}

Seed yield is not influenced by herbicides and application times.

Regardless of application time, the lowest percentage of normal seedlings after the germination, first count and accelerated aging tests was shown by seeds from plants desiccated with the herbicide glufosinate ammonium.

The herbicide glyphosate reduces seedling vigor.

Application times of paraquat dichloride do not affect the germination and vigor of bean seeds.

\section{References}

BOTELHO, F. J. E.; GUIMARÃES, R. M; OLIVEIRA, J. A.; EVANGELIST, J. R. E.; ELOI, T. A.; BALIZA, D. P. Desempenho fisiológico de sementes de feijão colhidas em diferentes períodos do desenvolvimento. Ciência Agrotecnologia, v.34, n.4, p.900-907, 2010. http://dx.doi.org/10.1590/S141370542010000400015

BRASIL. Ministério da Agricultura, Pecuária e Abastecimento. Regras para análise de sementes. Ministério da Agricultura, Pecuária e Abastecimento. Secretaria de Defesa Agropecuária. Brasília: MAPA/ACS, 2009. 395p. http:// www.agricultura.gov.br/arq_editor/file/2946_regras_analise_sementes.pdf

CAIERÃO, E.; ACOSTA, A. S. Uso industrial de grãos de cevada de lavouras dessecadas em pré-colheita. Pesquisa Agropecuária Brasileira, v.42, n.9, p.1277-1282, 2007. http://seer.sct.embrapa.br/index.php/pab/article/view/7695

COELHO, C. M. M.; MOTA, M. R.; SOUZA, C. A.; MIQUELLUTI, D. J. Potencial fisiológico em sementes de cultivares de feijão crioulo (Phaseolus vulgaris L.). Revista Brasileira de Sementes,v.32, n. 3, p. 97-105, 2010. http://www.scielo.br/pdf/rbs/v32n3/v32n3a11.pdf
COELHO, C. M. M.; SOUZA, C. A.; ZILIO, M.; MICHELS, A. F. Ação de dessecante na pré-colheita sobre a produtividade e a qualidade fisiológica de sementes crioulas de feijoeiro. Semina: Ciências Agrárias, v.33, n.1, p.29732980, 2012. http://www.uel.br/revistas/uel/index.php/semagrarias/article/ view/8001/11790

DALTRO, E. M. F.; ALBUQUERQUE, M. C. F.; FRANÇA-NETO, J. B.; GUIMARÃES, S. C.; GAZZIERO, D. L. P.; HENNING, A. A. Aplicação de dessecantes em pré-colheita: efeito na qualidade fisiológica de sementes de soja. Revista Brasileira de Sementes, v. 32, n. 1, p. 111-122, 2010. http:// www.scielo.br/pdf/rbs/v32n1/v32n1a13.pdf

EMBRAPA. Centro Nacional de Pesquisa de Solos. Sistema brasileiro de classificação de solos,2. ed, 2006, 412p.

FOLONI, J. S. S.; HIRATA, A. C. S.; PEREIRA, D. N.; CARVALHO, M. L. M.; CASAVECHIA, D. Dessecação química em pré-colheita da mamona. Revista Ceres, v. 58, n. 5, p. 665-669, 2011. http://www.scielo.br/scielo. php?script=sci_arttext\&pid=S0034-737X2011000500019

FRANÇA-NETO, J. B.; KRZYZANOWSKI, F. C.; PÁDUA, G. P.; COSTA, N. P.; HENNING, A. A. Tecnologia da produção de semente de soja de alta qualidade:Série Sementes. Londrina, PR: Embrapa Soja. 2007. 12p. (Circular Técnica 40)

GUIMARÃES, V. F.; HOLLMANN, M.J.; FIOREZE, S.L.; ECHER, M.M.; RODRIGUES-COSTA, A.C.P.; ANDREOTTI, M. Produtividade e qualidade de sementes de soja em função de Estádios de dessecação e herbicidas. Planta Daninha, v.30, n.3, p.567-573, 2012. http://www.scielo.br/scielo. php?pid=S0100-83582012000300012\&script=sci_arttext

KAMIKOGA, Á. T. M.; KAMIKOGA, M. K.; TERASAWA, J. M.; ROMANEK, C.; PENKAL, K. F. Efeito de diferentes épocas de aplicação de três herbicidas dessecantes na produção e qualidade fisiológica de sementes de feijão. Ciências Exatas e da Terra, Ciências Agrárias e Engenharia, v.15, n.1, p.53-61, 2009. http://www.revistas2.uepg.br/index.php/exatas/article/view/975 
KAPPES, C.; ORSI, J. V. N.; JESUS JÚNIOR, A. M.; CARVALHO, M. A. C. Efeitos dos dessecantes diquat e paraquat no potencial produtivo da cultura da soja. Cultura Agronômica, v.17, p.57-67, 2008. http:// www.scielo.br/scielo.php?script $=$ sci_nlinks\&ref=000116\&pid=S0034737X201200010000800013\&lng=en

KAPPES, C.; CARVAlhO, M. A. C.; YAmashitA, O. M. Potencial fisiológico de sementes de soja dessecadas com diquat e paraquat. Scientia Agraria, v.10, n.1, p.1-6, 2009. http://ojs.c3sl.ufpr.br/ojs/index.php/agraria/ article/view/12520

KAPPES, C.; ARF, O.; FERREIRA, J. P.; PORTUGAL, J. R.; ALCALDE, A. M.; ARF, M. V.; VILELA, R. G. Qualidade fisiológica de sementes e crescimento de plântulas de feijoeiro, em função de aplicações de paraquat em pré-colheita. Pesquisa Agropecuária Brasileira, v.42, n.1, p.9-18, 2012. http://www.revistas.ufg.br/index.php/pat/article/view/13096

KIKUTI, H.; ANDRADE, M. J. B.; KIKUTI, A. L. P.; PEREIRA, C. P. Qualidade de sementes de genótipos de feijão em função da adubação. Revista Ciência Agronômica, v.37, n. 1, p.37-46, 2006. http://www.ccarevista.ufc.br/ seer/index.php/ccarevista/article/view/218

LACERDA, A. L. S.; LAZARINI, E.; SÁ, M. E.; WALTER FILHO, V. V. Efeitos da dessecação de plantas de soja no potencial fisiológico e sanitário das sementes. Bragantia, v.64, p.447-457, 2005. http://www.redalyc.org/ articulo.oa?id=90864315

MAGUIRE, J. D. Speed of germination - aid in selection and evaluation for seedlings emergence and vigor. Crop Science, v.2, n.1, p.176-177, 1962. https://www.crops.org/publications/cs/abstracts/2/2/CS0020020176

MARCOS-FILHO, J. Fisiologia de sementes de plantas cultivadas. Piracicaba: FEALQ, 2005. 495p.
MOURA, J. Z.; PÁDUA, L. E. M.; MOURA, S. G.; TORRES, J. S.; SILVA, P. R. R. Escala de desenvolvimento fenológico e exigência térmica associada a grausdia do feijão-caupi. Revista Caatinga, v.25, n.3, p.66-71, 2012. http://periodicos ufersa.edu.br/revistas/index.php/sistema/article/viewFile/2107/pdf 11

ROCHA, V. P. C.; MODA-CIRINO, V.; DESTRO, D.; FONSECA JÚNIOR, N. S.; PRETE, C. E. C. Adaptabilidade e estabilidade da característica produtividade de grãos dos grupos comerciais carioca e preto de feijão. Semina: Ciências Agrárias, v.31, n.1, p.39-54, 2010. http://www.uel.br/ revistas/uel/index.php/semagrarias/article/view/4888

SANTOS, J. B.; FERREIRA, E. A.; SANTOS, E. A.; SILVA, A. A.; SILVA, F. M.; FERREIRA, L. R. Qualidade de sementes de feijão (Phaseolus vulgaris L.) após aplicação do carfentrazoneethyl em pré-colheita. Planta Daninha, v.22, n.4, p.633-639, 2004. http://www.scielo.br/scielo.php?pid=s0100$83582004000400019 \&$ script $=$ sci_arttext

SAS - Institute. SAS Institute Inc ${ }^{\circledR}$. 2003. Cary, NC, USA, Version 8.0http:// www.scielo.br/scielo.php? script $=$ sci nlinks\&ref $=000115 \&$ pid $=$ S0103 $8478201400020002400030 \& \operatorname{lng}=\mathrm{en}$

PENCKOWSKI, L. H. Dessecação obrigatória. Cultivar Grandes Culturas, p. 26-29, 2005.

VARGAS, L.; MORAES, R. M. A.; BERTO, C. M. Herança da resistência de azevém (Loliumm ultiflorum) ao glyphosate. Planta Daninha, v.25, n.3, p.567-571, 2007. http://www.scielo.br/scielo.php?script=sci arttext\&pid $=$ S0100-83582007000300016

VIEIRA, C.; PAULA JUNIOR, T. J.; BORÉM, A. Feijão. 2. ed. Viçosa, MG Ed. UFV, 2006. 63p. 